\title{
WATER MANAGEMENT FOR SESAME CROP IN SANDY SOIL
}

\author{
Sharaf, G. A. ${ }^{1}$ Khalil A. ${ }^{2}$ Azza H. ${ }^{2}$ Hashem M. ${ }^{3}$
}

\begin{abstract}
The main objective of this study was to investigate the proper water regime of sesame crop under different irrigation methods in sandy soil in Egypt, Bostan West Delta. Two successive growing seasons of sesame production were conducted during 2013 and 2014 by the use of split plot design. The irrigation regime treatments were to apply $80 \%, 100 \%$ and $120 \%$ of the crop evapotranspiration. The three methods of irrigation were drip surface, drip subsurface and sprinkler methods. The irrigation intervals were 2 days and 4 days for the drip and sprinkler systems respectively. A seasonal water consumptive use by sesame were 490, 465 and $525 \mathrm{~mm} / \mathrm{season}$ for drip surface, drip subsurface and sprinkler irrigation system respectively. Average irrigation applied water was $2641 \mathrm{~m}^{3} / \mathrm{fed}, 2496 \mathrm{~m}^{3} / \mathrm{fed}$ and $4193 \mathrm{~m}^{3} / \mathrm{fed}$ by the drip surface, drip subsurface and sprinkler systems respectively. The corresponding average seed yields were 557, 555 and $585 \mathrm{~kg} / \mathrm{fed}$.. Significant difference was found in seed production due to the irrigation system and the irrigation regime. The average oil yields were 237, 244 and $249.8 \mathrm{~kg} / \mathrm{fed}$. for the same previous order. The WUE of seeds and oil affected significantly by both the irrigation systems and irrigation regime. A high correlation was found between the biological yield and plant height, No. of capsules/plant and weight of dry seeds/plant as 0.86, 071 and 0.94 respectively. The yield functions of seeds and oil were non linear. A set of yield functions for seeds and oil under the different irrigation system were performed. The results indicated that when applying maximum irrigation water $2620 \mathrm{~m}^{3} / \mathrm{fed}$., the subsurface drip irrigation system produced 702.6 $\mathrm{kg}$ seeds/fed. and $311.4 \mathrm{~kg}$ oil/fed., meanwhile the surface drip irrigation system produced $686.5 \mathrm{~kg}$ seeds/fed. and $304.8 \mathrm{~kg}$ oil/fed. when 2798.2 $m^{3}$ water was added per fed.
\end{abstract}

\footnotetext{
${ }^{1}$ Prof. of Agric. Eng., Soil Dept. Fac. of Agric, Saba- Basha, Alex. Univ.

2 Senior Res., Agric. Eng. Res. Institute

${ }^{3}$ Res., Agric. Eng. Res. Institute
} 
The sprinkle irrigation system produced $616.7 \mathrm{~kg}$ seeds/fed. and $268.1 \mathrm{~kg}$ oil/fed. when $4010.3 \mathrm{~m}^{3}$ water was added per fed.. Among all the study treatments, the application of subsurface drip irrigation system at 100\% of ETc indicated the best results related with the yield of seeds and oil and the other yield components, Although, there is no significant difference between the irrigation water used between the subsurface drip and surface drip irrigation.

\section{INTRODUCTIOPN}

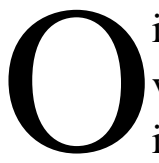
il crops are the source of edible and industrial oil with a wide variety of usage as well as of protein meals. Sesame (Sesamum indicumL.) is one of the most important oil crop in the world because seeds have high content of oil and protein. In Egypt most of the seed production is consumed as edible products such as Tehena, Halawa Tahiniya and bakery products. The total production of edible oil is about $10 \%$ of the consumption in Egypt. Therefore, many attempts are being made to raise total production of oil crops particularly sesame for narrowing Manal et al. (2007) recommended to apply five irrigations to sesame with total amounts of water between 4367 and $4728 \mathrm{~m}^{3} / \mathrm{ha}$, which could save up to $1027 \mathrm{~m} 3 / \mathrm{ha}$, with yield losses less than $2 \%$. Erkan et al. (2007) evaluated the effect of the irrigation methods and intervals on yield and yield components of sesame. They found that when $971 \mathrm{~mm}$ of water was applied, evapotranspiration (ETc) of sesame was $995 \mathrm{~mm}$ for sprinkler, $1102 \mathrm{~mm}$ for drip in $1^{\text {st }}$ season. For $2^{\text {nd }}$ season total water applied was $1037 \mathrm{~mm}$ and evapotranspiration of sesame was $1111 \mathrm{~mm}$ (sprinkler), 1135mm (drip). Plant height and number of capsules per plant were significantly affected by drip irrigation. Average sesame yield was $1737 \mathrm{~kg} \mathrm{ha}^{-1}$ for drip irrigation while sprinkler irrigation gave $1283 \mathrm{~kg}$ $\mathrm{ha}^{-1}$.El-Wakil and Gaaffar (1988) indicated that applying six irrigations to sesame crop without skipping any one gave the highest values of yield and its attributes, whereas the lowest values were resulted from applying five irrigations and skipping one at the beginning of flowering. Applying three, four, five and six irrigations gave seasonal ETc of 1323, 1382, 1487 and $1647 \mathrm{~m}^{3} / \mathrm{fed}$, respectively. Moreover, applying six irrigations gave the highest WUE value as $0.35 \mathrm{~kg}$ seeds $/ \mathrm{m}^{3}$ of water consumed. Kassab et al. (2005) found that irrigation regime of $100 \%\left(1839 \mathrm{~m}^{3} / \mathrm{fed}.\right)$ in 
controlled surface irrigation and $999 \mathrm{~m}^{3} / \mathrm{fed}$. in both sub-surface and surface drip irrigation caused significant increases in the growth parameters, yield and its related traits as well as seed oil content, yield and WUE. The obtained results suggested that controlled surface irrigation system and irrigation regime of $100 \%$ of ETc could be recommended for improving productivity of sesame plants under similar conditions.

The main objectives of this work are:

1. Study the effect of three different irrigation methods (drip surface, drip subsurface and sprinkler) at three levels of irrigation regimes (100\% (control), 80 and $120 \%$ from normal irrigation requirements) on the production of Sesame crop.

2. Determine the yield function and the water relation to Sesame yield components.

3. Evaluate the irrigation system used.

\section{MATERIAL AND METHODS}

\section{Field Experimental Site:}

Two field experiments were carried out during two successive seasons of 2013 and 2014 at Ahmed Ramy Village - Al-Bostan. The physical and chemical properties of the experimental site are presented in Tables (1) and (2). The parameters were determined according to Black et al. (1985).

Table (1): Physical properties of the soil

\begin{tabular}{|c|c|c|c|c|c|c|c|c|c|c|}
\hline $\begin{array}{c}\text { Soil } \\
\text { depth } \\
(\mathrm{cm})\end{array}$ & \multicolumn{2}{|c|}{$\begin{array}{c}\text { Particle size } \\
\text { distribution }(\%)\end{array}$} & $\begin{array}{c}\text { Soil } \\
\text { texture } \\
\text { class }\end{array}$ & $\begin{array}{c}\text { b.d } \\
\mathrm{g} \mathrm{cm}^{-3}\end{array}$ & $\begin{array}{c}\theta_{\mathrm{s}} \\
\mathrm{m}^{3} \mathrm{~m}^{-3}\end{array}$ & $\begin{array}{c}\text { F.C } \\
\mathrm{m}^{3} \mathrm{~m}^{-3}\end{array}$ & $\begin{array}{c}\text { P.W.P } \\
\mathrm{m}^{3} \mathrm{~m}^{-3}\end{array}$ & $\begin{array}{c}\text { Aval. } \\
\text { Water } \\
\mathrm{m}^{3} \mathrm{~m}^{-3}\end{array}$ & $\begin{array}{c}k_{s} \\
\mathrm{~mm} \mathrm{~h}^{-1}\end{array}$ \\
\hline $0-30$ & 87 & 4 & 9 & $\begin{array}{c}\text { Loamy } \\
\text { Sand }\end{array}$ & 1.45 & 0.47 & 0.13 & 0.054 & 0.076 & 128 \\
\hline $30-60$ & 88 & 4 & 8 & $\begin{array}{c}\text { Loamy } \\
\text { Sand }\end{array}$ & 1.48 & 0.46 & 0.12 & 0.062 & 0.058 & 132 \\
\hline Aver. & 87.5 & 4 & 8.5 & $\begin{array}{c}\text { Loamy } \\
\text { Sand }\end{array}$ & 1.465 & 0.465 & 0.125 & 0.058 & 0.067 & 130 \\
\hline
\end{tabular}

The field was plowed, and leveled to provide a smooth seedbed. Cultivating management included application of Calcium super phosphate and potassium sulphate at the rates of 200 and $50 \mathrm{~kg} / \mathrm{fed}$. respectively, were added before planting and weeds control. Sesame seeds (Sesamum 
indicum L.) cv. Shandweel 3 was sown in hills, with a distance of $0.10 \mathrm{~m}$ between hills and $0.60 \mathrm{~m}$ between rows. The normal agricultural practices for growing sesame were followed as recommended in the region. Nitrogen fertilizer added as ammonium nitrate $33.5 \%$ at the rate of 100 $\mathrm{kg} / \mathrm{fed}$. applied in three doses the $1^{\text {st }}$ after thinning then $2^{\text {nd }}$ and $3^{\text {rd }}$ through one month.

Table (2): chemical properties of the soil

\begin{tabular}{|c|c|c|c|c|c|c|c|c|c|c|c|}
\hline \multirow{2}{*}{$\begin{array}{c}\begin{array}{c}\text { Soil } \\
\text { depth } \\
(\mathrm{cm})\end{array} \\
\end{array}$} & \multirow{2}{*}{$\begin{array}{l}\mathrm{EC}_{\mathrm{e}} \\
\mathrm{dS} / \mathrm{m}\end{array}$} & \multirow{2}{*}{$\mathrm{pH}$} & \multirow{2}{*}{$\begin{array}{c}\text { Total } \\
\mathrm{CaCO}_{3} \\
\% \\
\end{array}$} & \multirow{2}{*}{ O.M } & \multicolumn{4}{|c|}{ Soluble cations (meq/l) } & \multicolumn{3}{|c|}{ Soluble anions (meq/l) } \\
\hline & & & & & $\mathrm{Ca}^{2+}$ & $\mathrm{Mg}^{2+}$ & $\mathrm{Na}^{+}$ & $\mathrm{K}^{+}$ & $\mathrm{HCO}_{3}$ & $\mathrm{SO}_{4}{ }^{2-}$ & $\mathrm{Cl}^{-}$ \\
\hline $0-30$ & 5.32 & 7.9 & 10.5 & 0.7 & 16.75 & 14.3 & 27.4 & 0.55 & 3.5 & 31.8 & 23.7 \\
\hline $30-60$ & 5.15 & 8.0 & 10.7 & 0.8 & 17.75 & 14.6 & 27.3 & 0.55 & 3.7 & 32.5 & 24 \\
\hline Aver. & 5.235 & 7.9 & 10.6 & 0.75 & 17.25 & 14.45 & 27.35 & 0.55 & 3.6 & 32.15 & 23.85 \\
\hline
\end{tabular}

\section{Irrigation Systems:}

1- Surface and subsurface drip irrigation systems were used GR (4 l/h) lateral per row. The different components and parameters of the drip irrigation systems are summarized in Table (3).

Table (3): Specifications of surface and subsurface drip irrigation networks.

\begin{tabular}{|l|l|l|l|}
\hline Drip lateral & GR & emitter spacing $(\mathrm{m})$ & 0.3 \\
\hline PVC main line diameter $(\mathrm{mm})$ & 75 & Operating pressure $(\mathrm{kPa})$ & 150 \\
\hline PVC submain diameter $(\mathrm{mm})$ & 63 & Pump discharge $\left(\mathrm{m}^{3} / \mathrm{h}\right)$ & 45 \\
\hline PVC. lateral diameter $(\mathrm{mm})$ & 50 & Pump pressure head $(\mathrm{kPa})$ & 380 \\
\hline manifold diameter(mm) & 18 & Power of elect. motor $(\mathrm{kW})$ & 15 \\
\hline Surface emitter flow rate $(l / \mathrm{h})$ & 3.49 & $\begin{array}{l}\text { Sub surface emitter flow } \\
\text { rate }(l / \mathrm{h})\end{array}$ & 3.76 \\
\hline
\end{tabular}

\section{Drip Irrigation System Evaluation:}

The emission uniformity EU, and the absolute uniformity, EU'a, as proposed by Walker, (1980), were applied for field evaluation of the drip surface and subsurface systems as:

Where:

$$
\begin{aligned}
& E U^{`}=\frac{\text { qave }_{1 / 4}}{\text { qave }} * 100 \\
& E U^{`} a=\frac{1}{2} *\left[\frac{\text { qave }_{1 / 4}}{\text { qave }}+\frac{\text { qave }}{\text { qave }_{1 / 8}}\right] * 100
\end{aligned}
$$


qave $_{1 / 4}$ the average of the lower $1 / 4$ of the emitter discharge rates.

qave the average of all emitter discharge rates.

qave $_{1 / 8}$ the average of largest $1 / 8$ of the emitter discharge rates.

2- Fixed sprinkler irrigation systems were used. The components and parameters of the irrigation system network at the experimental site are summarized in Table (4). The discharge from the sprinkler jet was calibrated as recommended by the ASAE Standards (2001). The pressure was measured at the field using a hypodermic needle assembly and dial pressure gage. The sprinkler irrigation system uniformity was carried out using catch can test.

Table (4): Specifications of sprinkler irrigation network.

\begin{tabular}{|l|c|l|c|}
\hline \multicolumn{1}{|c|}{ Sprinkler size } & $\begin{array}{c}\text { RC235 } \\
(\varnothing 4.36 \times 2.25 \\
\mathrm{mm})\end{array}$ & PVC. lateral diameter mm & 63 \\
\hline Raiser height & $120 \mathrm{~cm}$ & Sprinkler spacing $(\mathrm{m})$ & $12 \times 12$ \\
\hline Steel riser diameter $(\mathrm{mm})$ & 26.7 & PVC main line diam. $(\mathrm{mm})$ & 110 \\
\hline Working pressure $(\mathrm{kPa})$ & 210 & Pump pressure head $(\mathrm{kPa})$ & 380 \\
\hline sprinkler flow rate $\left(\mathrm{m}^{3} / \mathrm{h}\right)$ & 1.05 & Motor elect. power $(\mathrm{kW})$ & 15 \\
\hline
\end{tabular}

\section{Sprinkler Irrigation System Evaluation:}

The Distribution Uniformity (DU) by Marriam and Keller (1978) was applied to calculate the uniformity of application, as:

$$
D U=\frac{\text { qave }_{1 / 4}}{\text { qave }} * 100
$$

Where:

qave1/4 average of low quarter of water received

qave average depth of water received

The Coefficient of Uniformity CU developed by Christiansen (1942) as:

where

$$
C U=100\left[1-\frac{\sum|z-m|}{n \cdot m}\right]
$$

$\mathrm{z} \quad$ individual depth of each observation from the uniformity test (mm)

$\mathrm{m} \quad$ mean depth of water $(\mathrm{mm})$

$\mathrm{n} \quad$ number of catch cans 
Water application efficiency (Ea) as defined by $\mathbf{L i}$ and $\mathbf{R a o}$ ( 2004) as:

$$
E a=\frac{d_{t}}{d_{a}} \times 100
$$

Where:

$\mathrm{d}_{\mathrm{t}} \quad$ average depth of irrigation water received by the catch cans $(\mathrm{mm})$

$d_{a} \quad$ average depth of irrigation water applied (sprinkler application rate for a given time $\mathrm{mm}$ )

Both of the drip (surface and subsurface) and sprinkler irrigation systems were evaluated before planting, forty days after planting and after harvesting. Repair, maintenance, was conducted before each growing season.

\section{Sesame Crop Coefficient:}

The sesame crop coefficients at different growing stages, stage length cited from FAO Report No. 56 by Allen et al., 1998 is given in Table. (5).

Table (5): Sesame basic data cited from FAO report No.(56).

\begin{tabular}{|l|c|c|c|c|}
\hline \multicolumn{1}{|c|}{ Stage } & Initial & Development & Mid- season & $\begin{array}{c}\text { Late - } \\
\text { season }\end{array}$ \\
\hline Coefficient & 0.35 & - & 1.1 & 0.25 \\
\hline Length (days) & 20 & 40 & 30 & 20 \\
\hline
\end{tabular}

\section{Adjustment of Sesame crop Coefficients :}

The initial stage coefficient $\left(\mathrm{Kc}_{\text {ini }}\right)$ in the FAO tables are only approximations and should only be used for estimating $\mathrm{ET}_{\text {crop }}$ during preliminary or planning studies. More accurate estimates of $\mathrm{Kc}_{\text {ini }}$ can be obtained by considering, the interval between wetting, events, evaporation power of atmosphere and the magnitude of the wetting events. During the initial period the leaf area is small and evapotranspiration is predominately in the form of soil evaporation. The graphical method (Allen et al., 1998) was used to adjust $\mathrm{Kc}_{\mathrm{ini}}$. For the drip and sprinkler irrigation systems the frequencies were two and four days; ETo was 6.7 $\mathrm{mm}$ during the $\mathrm{Kc}_{\mathrm{ini}}$ and the irrigation depths were $<10 \mathrm{~mm}$ for drip and > $40 \mathrm{~mm}$ b for sprinkler. From Fig. (29) and Fig. (30) (Allen et al., 1998) 
$\mathrm{Kc}_{\mathrm{ini}}$ is about 0.65 and 0.5 , for drip and sprinkler irrigation respectively. Further adjustment to the $\mathrm{Kc}_{\text {ini }}$ was done by considering the partial wetting in the drip system as:

$$
K c_{i n i}=f w \cdot K c_{i n i}
$$

$f w$ is the fraction of surface wetted by irrigation ranged between $0-1$. By observation $f w$ was about 0.7 for surface drip system meanwhile 0.5 for the sub surface drip system. Therefore, the $\mathrm{Kc}_{\text {ini }}$ of the Sesame for the surface drip system became 0.46 and for the subsurface as 0.33 .

The values of $\mathrm{Kc}_{\text {mid }}$ and $\mathrm{Kc}_{\text {end }}$ given by FAO report No.56 for a sub humid where $\mathrm{RH}_{\min }$ differ from $45 \%$ or where $\mathrm{U}_{2}$ is larger or smaller than $2 \mathrm{~m} / \mathrm{s}, \mathrm{Kc}_{\mathrm{mid}}$ and $\mathrm{Kc}_{\text {end }}$ values are adiusted as:

$$
\begin{aligned}
& K c_{\text {end }}=K c_{\text {end-Tab }}+\left[0.04\left(U_{2}-2\right)-0.004\left(R H_{\text {min }}-45\right)\right]\left[\frac{h}{3}\right]^{0.3} \\
& K c_{\text {mid }}=K c_{\text {mid-Tab }}+\left[0.04\left(U_{2}-2\right)-0.004\left(R H_{\text {min }}-45\right)\right]\left[\frac{h}{3}\right]^{0.3}
\end{aligned}
$$

Where:

$K c_{\text {-mid }} \quad$ adjusted sesame mid- season coefficient.

$K c_{\text {-mid-Tab }}$ tabulated value of mi-season sesame coefficient (Allen, et al., 1998).

$K c_{\text {-end }} \quad$ adjusted sesame late-season coefficient.

$K c_{\text {-mid-Tab }}$ tabulated value of mi-season sesame coefficient.

$U_{2} \quad$ mean value of daily wind speed at $2 \mathrm{~m}$ height $(\mathrm{m} / \mathrm{s})$.

$R H_{\text {min }} \quad$ mean value of minimum relative humidity (\%).

$H \quad$ Plant height (m).

The minimum relative humidity and wind speed during the growing season on the experimental site are presented in Table (6). According to these values the midseason sesame coefficient adjusted to 1.2 instead of 1.1 and the late season adjusted to 0.35 instead of 0.25 . The final crop coefficient of sesame at different grown stages and irrigation systems presented in Table (7).

Table (6): Weather data for adjusting crop coefficient at mid and late season.

\begin{tabular}{|c|c|c|}
\hline & $\mathrm{RH}_{\min } \%$ & $\mathrm{U}_{2} \mathrm{~m} / \mathrm{s}$ \\
\hline Mid- season & 36.65 & 4.69 \\
\hline Late - season & 40.25 & 5.01 \\
\hline
\end{tabular}


Table (7): Final adjusted Sesame crop coefficients

\begin{tabular}{|c|c|c|c|c|}
\hline \multirow{2}{*}{ System type } & \multicolumn{4}{|c|}{ Stage } \\
\cline { 2 - 5 } & Initial & Development & Mid- season & Late season \\
\hline Drip surface & 0.46 & - & 1.2 & 0.35 \\
\hline Drip subsurface & 0.33 & - & 1.2 & 0.35 \\
\hline Sprinkler & 0.50 & - & 1.2 & 0.35 \\
\hline
\end{tabular}

The sesame daily Kc during the initial and mid-season stages are constants and during the development and late-season stages vary linearly between the end of the previous stage and the beginning of the next stage and

$$
K c(i)=K c_{\text {prev. }}+\left[\frac{i-\sum L_{\text {prv. }}}{L_{\text {stage }}}\right]\left(K c_{\text {next }}-K c_{\text {prev }}\right)
$$

calculated as:

Where:

$K c$ (i) crop coefficient of the day No. i

$K c_{\text {prev }} \quad \mathrm{Kcb}$ value of the previous stage

$L_{\text {stage }}$ length of the stage under consideration (days)

$\Sigma\left(L_{\text {prev }}\right) \quad$ sum of the lengths of the previous stages (days)

$K c_{\text {next }} \quad \mathrm{Kcb}$ value of the next stage

\section{Reference Evapotranspiration(ETo):}

ETo by Penman-Monteith was calculated using the climatic weather data that recorded by local meteorological weather station as described by Allen et. al., (1998).

\section{Sesame Water Requirements (ETcrop:}

The daily sesame water requirements were estimated by the following:

$$
\text { ETcrop }=\text { ETo } \times K c
$$

Where:

ETcrop Sesame ETc under sprinkler irrigation system ( $\mathrm{mm} /$ day)

$K c \quad$ Sesame crop coefficient. It may be for sprinkler, drip surface or sub surface.

In case of drip irrigation system the previous equation was applied in addition to multiply by another factor called reduction coefficient $(\mathrm{Kr})$. It was estimated according to Allen et al., (1998) by the following formula as: 


$$
K r=\frac{K c_{\min }}{K c_{\text {full }}}+\left[1-\frac{K c_{\min }}{K c_{\text {full }}}\right] \times G C^{\left(\frac{1}{1+h}\right)}
$$

Where:

$\mathrm{Kc}_{\min }$ minimum $\mathrm{Kc}$ for bar soil, in the presence of vegetation $(0.15-$ $0.2)$

$\mathrm{Kc}_{\text {full }} \quad \mathrm{Kc}$ during the mid- season at big plant size or height

Gc ground cover. By observations it was about $70 \%$ at mid season $\mathrm{H}$ plant maximum height $(\mathrm{m})$, for Sesame about $1 \mathrm{~m}$

\section{Gross Irrigation Water Requirements (GIWR):}

The general equations applied to calculate the GWR are as follows:

$$
G I W R=\frac{E T_{\text {crop }}}{E a \times k S} \times \frac{1}{L R}
$$

Where:

Ea irrigation system application efficiency

LR leaching requirements

Ks Coefficient of water storage of the soil, used in drip surface or subsurface only considered 0.9 for the sandy soil as proposed by Vermeiren and Jobling (1980).

\section{Leaching Requirements (LR):}

Leaching requirements to control the soil salinity, estimated according to Doorenbos and Pruit, (1977), who proposed the following formula for drip and high frequency sprinkler interval system. The following formula assumed to be valid for both irrigation systems applied:

$$
L R=\frac{E C_{w}}{2 \max E C e}
$$

where:

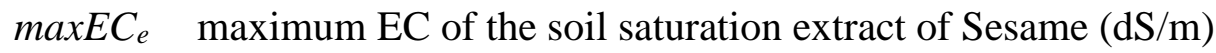

$E C_{w}$ electrical conductivity of the irrigation water $(\mathrm{d} S / \mathrm{m})$.

The average salinity of irrigation water $\left(\mathrm{EC}_{\mathrm{w}}\right)$ was $1.75 \mathrm{dS} / \mathrm{m}$, and the $\operatorname{maxEC}_{e}$ was $5.5 \mathrm{dS} / \mathrm{m}$, therefore, the leaching requirements is 0.16 for all the irrigation systems. 


\section{Irrigation Duration (Ti):}

The irrigation duration or the irrigation time for the drip surface or the subsurface was estimated by the following:

$$
T i_{\text {drip }}=\frac{G I W R \times I r \times S p \times S r}{q \times n e}
$$

Where:

$T i_{d r i p} \quad$ irrigation time to operate the surface or the subsurface irrigation system (h)

Ir irrigation interval 2 days, by surface or the subsurface irrigation systems (days)

$S p \quad$ distance between plants (m)

$\mathrm{Sr} \quad$ distance between rows $(\mathrm{m})$

$q \quad$ emitter flow rate $(l / \mathrm{h})$

ne number of emitters per plant.

The irrigation time for the sprinkler irrigation system $\left(T i_{s p r}\right)$ :

$$
T i_{s p r}=\frac{G I W R}{A_{r}}
$$

Where:

$A_{r} \quad$ sprinkler application rate by $(\mathrm{mm} / \mathrm{h})$. The application rate by the sprinkler was estimated by:

$$
A_{r}=\frac{Q_{S} \times 1000}{S \times R}
$$

Where:

Qs $\quad$ sprinkler discharge $\left(\mathrm{m}^{3} / \mathrm{h}\right)$

$\mathrm{S} \quad$ distance between sprinklers on lateral $(\mathrm{m})$

$\mathrm{R}$ distance between laterals (m)

\section{Sesame Crop Water Consumptive Use (WCU):}

Gravimetric soil samples, from soil surface down to $0.6 \mathrm{~m}$ depth at $0.2 \mathrm{~m}$ intervals were collected along the growing season of sesame from drip and sprinkler treatments before and after each irrigation to determine WCU (mm/day) which is considered (ETa). WCU was estimated according to Simonne and Dukes (2010) as:

$$
W C U=\frac{\sum D\left(\theta_{v i}-\theta_{v f}\right)}{100 \times N D}
$$


Where:

D thickness of the soil layer (mm)

$\boldsymbol{\theta}_{\boldsymbol{v} \boldsymbol{i}}$ initial volumetric soil moisture content (\%)

$\boldsymbol{\theta}_{\boldsymbol{v} f} \quad$ volumetric soil moisture content after irrigation (\%)

ND No. of days between initial and after irrigation

\section{Experimental Crop Coefficient of Sesame $\left(\mathrm{Kc}_{\mathrm{s}}\right)$}

Sesame experimental crop coefficient $\left(\mathrm{kc}_{\mathrm{s}}\right)$ values for the initial, mid and late season stages were calculated using the following equation as described by Allen et al. (1998):

$$
K c=\frac{W C U}{E T o}
$$

\section{Experimental Design:}

Split plot design (Fig. 1) with the main plot represents irrigation systems and the subplot for irrigation regimes. The irrigation systems were surface drip irrigation $\left(\mathrm{I}_{1}\right)$, subsurface drip irrigation $\left(\mathrm{I}_{2}\right)$ and sprinkler irrigation $\left(\mathrm{I}_{3}\right)$. The sub-plots included three application rates as deficit irrigation ( $\mathrm{D}=80 \%$ of ETc ), normal irrigation ( $\mathrm{N}=100 \%$ of ETc ) and excessive irrigation ( $\mathrm{E}=120 \%$ of ETc ) that commonly supplied in the region. Only the two central rows were used for sampling for each treatment.

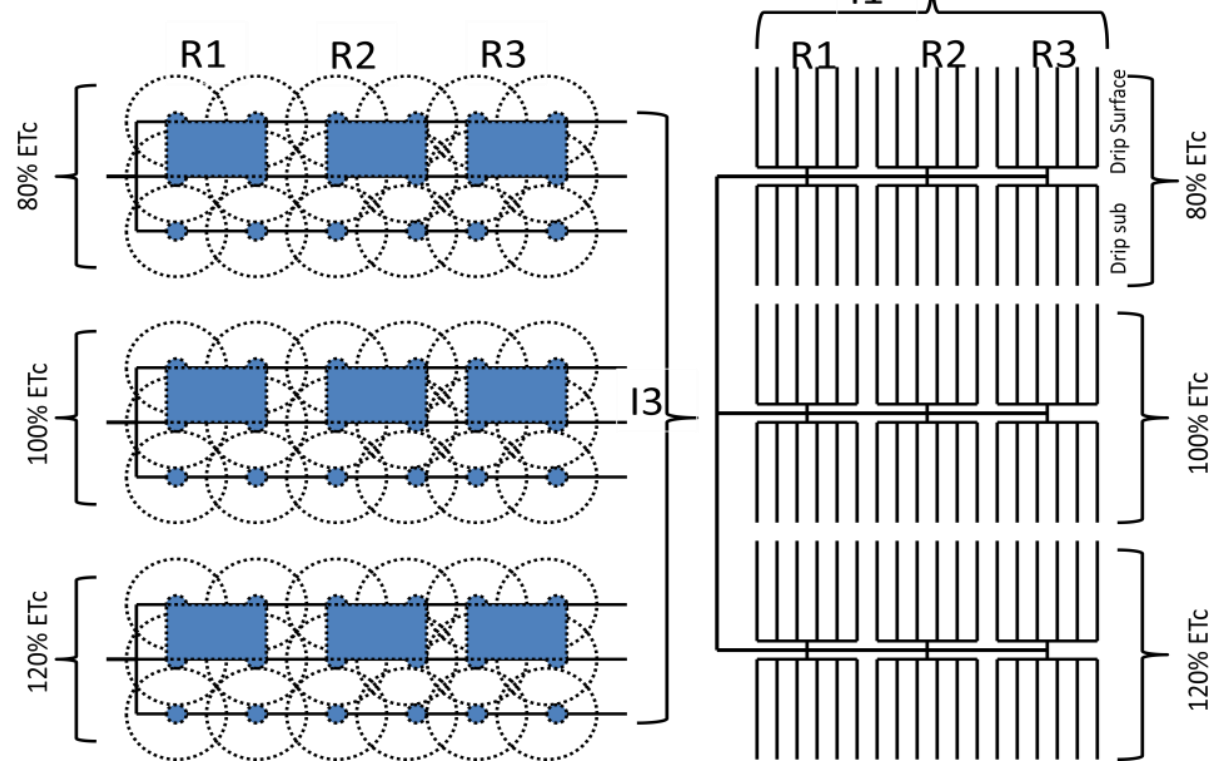

Fig. (1): Field experimental design layout 


\section{Water Use Efficiency (WUE):}

WUE a key term in the evaluation of water productivity in dimensions of $\left(\mathrm{kg} \mathrm{m}^{-3}\right)$ or $\left(\mathrm{Kg} \mathrm{ha}^{-1} \mathrm{~mm}^{-1}\right)$, proposed by Molden (2003).

\section{Yield and Yield Components:}

At harvest, samples of plants (area $1.2 \mathrm{~m}^{2}$ ) of a two central ridges were uprooted from each treatment randomly and topped to determine biological yield, plant length, number of capsules, weight of 1000 seeds, yield of seeds and oil and total seeds yield per feddan.

\section{Data Analysis:}

The data were analyzed using Costat 6.311 win statistical program CoHort Software (2005). Average values from the three replicates of each treatment were interpreted using the analysis of variance (ANOVA). The Duncan's Multiple Range Test (SNK) was used for comparisons among different sources of variance.

\section{RESULTS AND DISCUSION}

Field Evaluation of Drip Irrigation System:

The surface and subsurface drip irrigation systems evaluation parameters are given in Table (8).

General criteria for EU and EU a values are; $90 \%$ or greater, excellent; 80 to $90 \%$, good ; 70 to $80 \%$, fair; and less than $70 \%$, poor (Solomon, 1977). Results in Table (8), showed high values of both EU and EU'a which proves that the systems were managed and designed well (no clogging due to efficient filtration, no leakage, low flow variation and low hydraulic variation). The relationship between EU and EUa' showed linear function as given in Fig. (2).

Table(8): Parameters of field evaluation of the drip surface and subsurface irrigation systems

\begin{tabular}{|c|c|c|c|c|c|c|c|c|}
\hline \multirow{3}{*}{ Date } & \multicolumn{4}{|c|}{ First Season } & \multicolumn{4}{|c|}{ Second Season } \\
\hline & \multicolumn{2}{|c|}{ Subsurface } & \multicolumn{2}{|c|}{ Surface } & \multicolumn{2}{|c|}{ Subsurface } & \multicolumn{2}{|c|}{ Surface } \\
\hline & $\mathrm{EU}^{\prime}$ & EU`a & $\mathrm{EU}^{\prime}$ & EU`a & $\mathrm{EU}^{\prime}$ & EU`a & $\mathrm{EU}^{\prime}$ & EU`a \\
\hline $\begin{array}{l}\text { Before } \\
\text { planting }\end{array}$ & 94.14 & 94.96 & 94.92 & 95.35 & 94.92 & 95.35 & 95.11 & 96.42 \\
\hline $\begin{array}{l}40 \text { days } \\
\text { after } \\
\text { planting }\end{array}$ & 91.81 & 91.17 & 93.47 & 94.20 & 93.48 & 91.81 & 91.44 & 90.87 \\
\hline $\begin{array}{c}\text { After } \\
\text { harvesting }\end{array}$ & 90.68 & 90.66 & 91.47 & 90.07 & 86.18 & 90.75 & 87.69 & 88.73 \\
\hline
\end{tabular}


Field Evaluation of Sprinkler Irrigation System:

Distribution Uniformity DU, Coefficient Uniformity CU and Water Application Efficiency were calculated before planting, forty days after planting and after harvesting, Results in Table (9).

Table (9): Results of sprinkle irrigation system field evaluation

\begin{tabular}{|c|c|c|c|c|c|c|}
\hline \multirow{2}{*}{ Date } & \multicolumn{3}{|c|}{ First Season } & \multicolumn{3}{c|}{ Second Season } \\
\cline { 2 - 7 } & $\mathrm{Ea}(\%)$ & $\mathrm{CU}(\%)$ & $\mathrm{DU}(\%)$ & $\mathrm{Ea}(\%)$ & $\mathrm{CU}(\%)$ & $\mathrm{DU}(\%)$ \\
\hline $\begin{array}{c}\text { Before } \\
\text { planting }\end{array}$ & 61.64 & 89.79 & 82.43 & 62.65 & 90.99 & 85.8 \\
\hline $\begin{array}{c}40 \text { days } \\
\text { after } \\
\text { planting }\end{array}$ & 62.63 & 88.6 & 83.92 & 60.12 & 88.49 & 82.93 \\
\hline $\begin{array}{c}\text { After } \\
\text { harvesting }\end{array}$ & 74.27 & 91.12 & 85.59 & 73.77 & 88.46 & 81.34 \\
\hline
\end{tabular}

DU>75\%, CU>84\% is recommended (Benami and Ofen 1984). Ea values over 80 is desirable, less than 60 not acceptable, between 60 and 80 is fair (ASCE 1978). According to these criteria the sprinkler irrigation system performance is acceptable. The relationship between $\mathrm{CU}$ and DU showed linear function as given in Fig. (3).

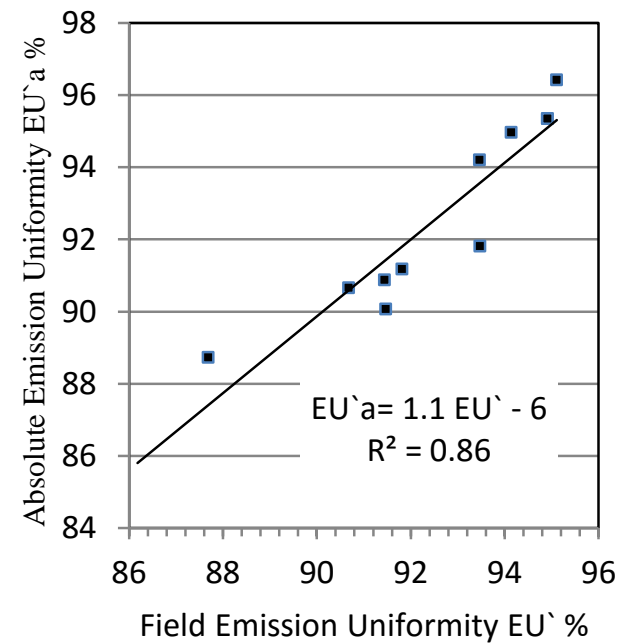

Fig.(2): The relationship between EU and EU'a

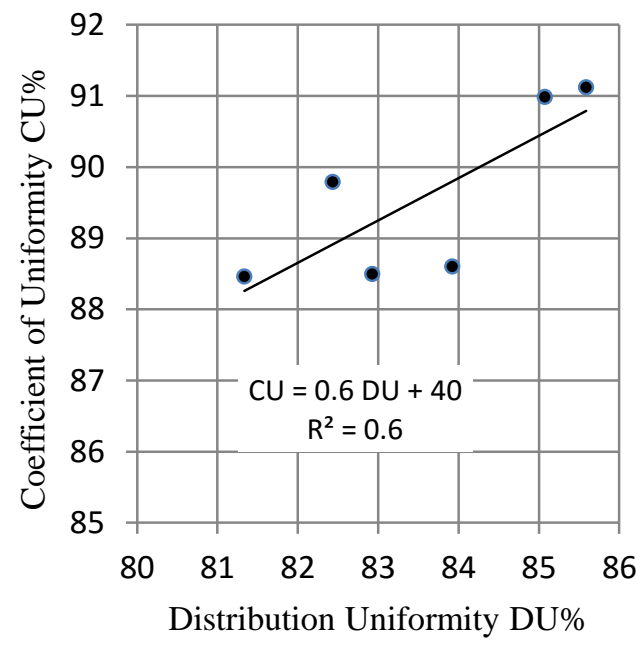

Fig.(3): The relationship between DU and $\mathrm{CU}$

\section{Sesame crop coefficient Kc:}

The Sesame crop coefficient cited from Allen, et al., (1998) was adjusted as given in Fig.(4). The actual water consumptive use (WCU) by plant and value of $\mathrm{Kc}$ was determined as a ratio between the measured WCU and ETo by Penman-Monteith. The experimental values of Kc compared 
with the numerical vales. The results presented in Fig.(5). The correlation coefficient between Kc calculated and measured were $0.885,0.873$ and 0.9 for surface drip, subsurface drip and sprinkler system respectively.

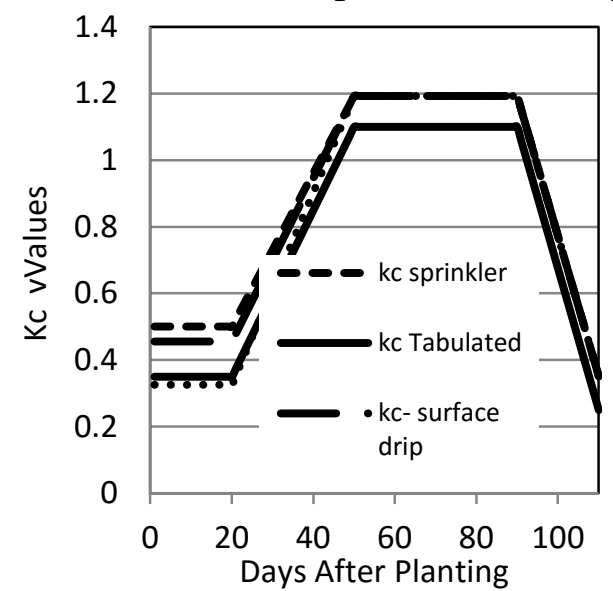

Fig. (4): Adjusted values of Sesame

Kc for irrigation systems

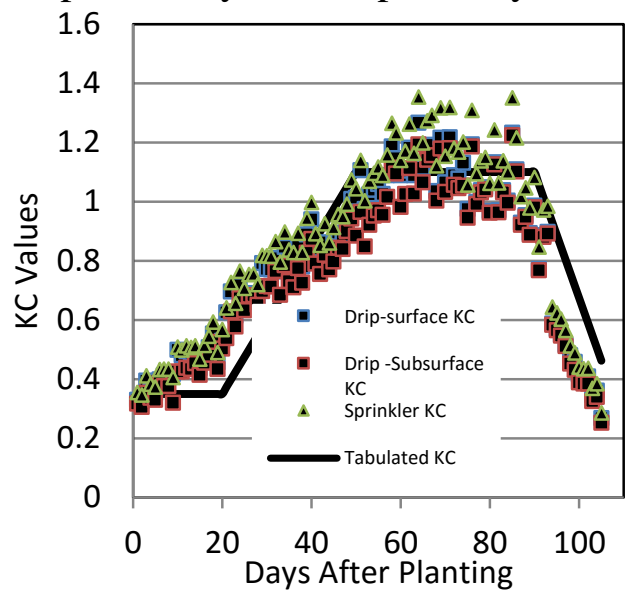

Fig.( 5): Tabulated and experimental vales of Sesame Kc

\section{Reference Evapotranspiration (ET $\mathbf{0})$ :}

Daily $\mathrm{ET}_{\mathrm{o}}$ along the growing season was calculated by Penman-Monteith equation. Values of $\mathrm{ET}_{\mathrm{o}}$ fluctuated due to the change of weather conditions as shown in Fig. (6). Seasonal ET $\underline{\underline{o}}$ was $762.1 \mathrm{~mm}$. ETo values during initial, development, mid-season and late season stages are shown in Table (10).

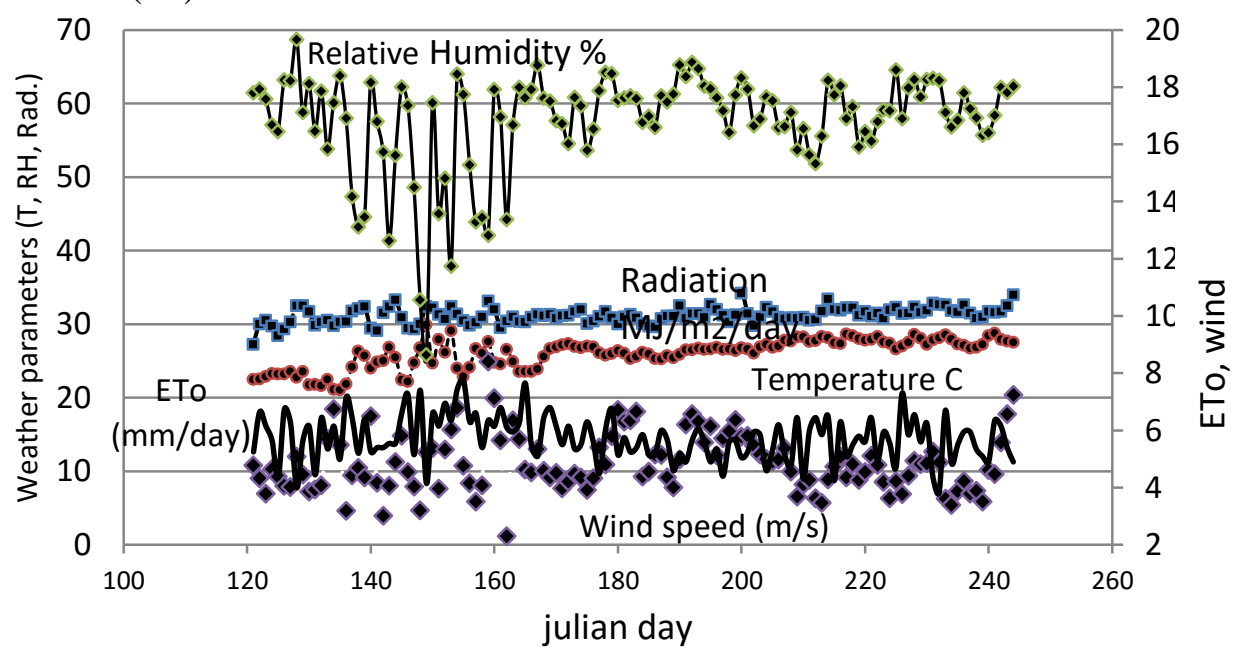

Fig. (6): ETo and weather data along the growing season of Sesame. 


\section{ET $_{\text {crop }}$ and Water Consumptive Use WCU by Sesame:}

Daily $E T_{\text {crop }}$ of sesame was estimated for sprinkler, surface and subsurface drip irrigation systems, results were presented in Fig. (7). The $E T_{\text {crop }}$ and WCU during initial, development, midseason and late season stages under the different irrigation systems are presented in Table (10). WCU under the irrigation methods were compared with ET $_{\text {crop. The }}$ results indicated that the relationships were linear as shown in Fig. (8), Fig.(9) and Fig(10). In all cases the WCU is less than $\mathrm{ET}_{\text {crop. }}$

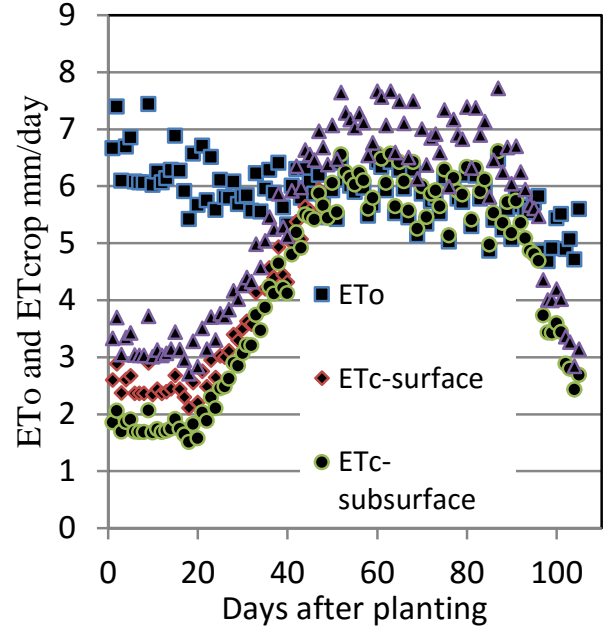

Fig. (7): ETcrop under sprinkler, drip surface and subsurface irrigation systems.

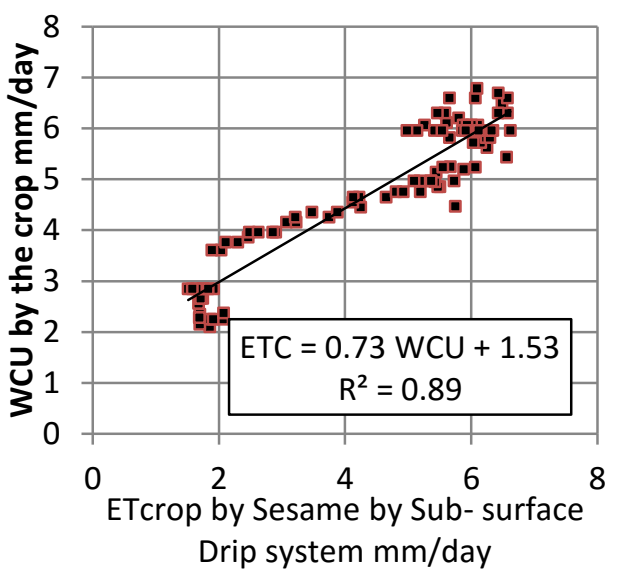

Fig. (9). The relationship between WCU and ETc under drip sub surface.

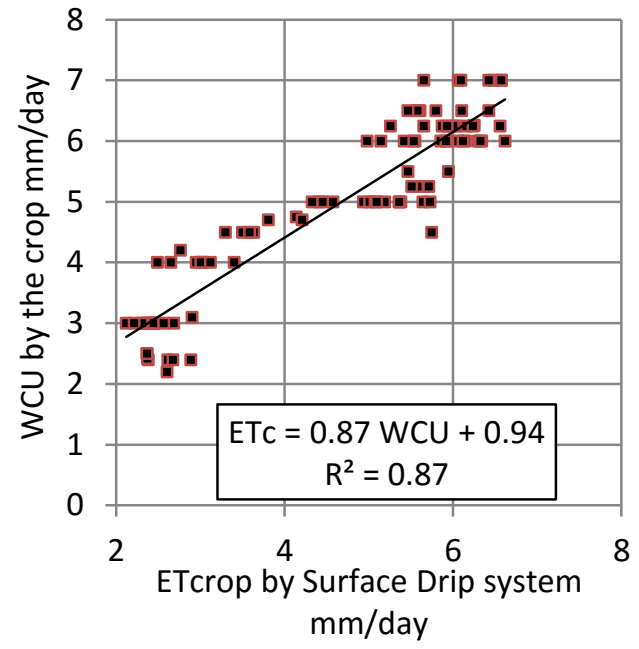

Fig. (8): The relationship between WCU and ETc under drip surface.

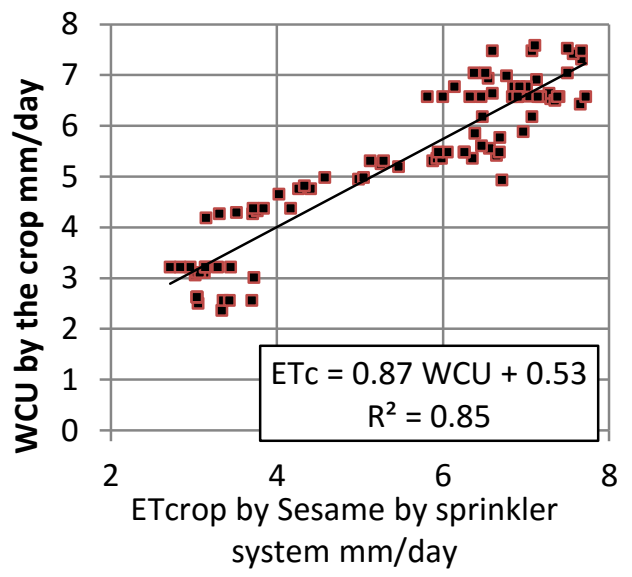

Fig. (10). The relationship between WCU and ETc under sprinkler system 


\section{Gross Irrigation Water Requirements Under Different Irrigation}

\section{Systems (GIWR):}

Irrigation water is added to replenish the soil moisture by crop daily consumptive use. For the drip system (surface or subsurface) the water applied day by day while the interval was 4 days for the sprinkler system. The GIWR under the different irrigation system and during the growing stages are recorded in Table.(10). The last 10 days before harvesting, the irrigation was terminated to increase the oil content in seeds.

Table (10): ETo, ETc, CU and GIWR at different growing stages and irrigation systems

\begin{tabular}{|c|c|c|c|c|c|}
\hline System & Stage & $\begin{array}{c}\text { ETo } \\
(\mathrm{mm})\end{array}$ & $\begin{array}{l}\text { ETc } \\
(\mathrm{mm})\end{array}$ & $\mathrm{WCU}(\mathrm{mm})$ & $\begin{array}{l}\text { GIWR } \\
(\mathrm{mm})\end{array}$ \\
\hline \multirow{4}{*}{$\begin{array}{l}\text { Drip } \\
\text { Surface }\end{array}$} & Initial & 126.9 & 49.5 & 59.5 & 69.3 \\
\hline & Development & 187.4 & 127.6 & 143.9 & 186.7 \\
\hline & Mid-Season & 326.9 & 232.0 & 248.1 & 317.4 \\
\hline & Late-Season & 84.9 & 64.2 & 38.2 & 55.4 \\
\hline \multicolumn{2}{|c|}{ Total / Season (mm) } & 762.1 & 473.3 & 490.0 & 628.8 \\
\hline \multirow{4}{*}{$\begin{array}{l}\text { Drip Sub- } \\
\text { surface }\end{array}$} & Initial & 126.9 & 35.4 & 54.4 & 49.6 \\
\hline & Development & 187.4 & 118.0 & 134.3 & 173.4 \\
\hline & Mid-Season & 326.9 & 232 & 238.5 & 317.9 \\
\hline & Late-Season & 84.9 & 64.2 & 37.1 & 55.4 \\
\hline \multicolumn{2}{|c|}{ Total / Season (mm) } & 762.1 & 449.6 & 465.0 & 596.3 \\
\hline \multirow{4}{*}{ Sprinkler } & Initial & 126.9 & 63.5 & 62.7 & 121.5 \\
\hline & Development & 187.4 & 158.0 & 153.0 & 304.8 \\
\hline & Mid-Season & 326.9 & 270.7 & 268.0 & 505.6 \\
\hline & Late-Season & 84.9 & 74.9 & 41.4 & 58.6 \\
\hline \multicolumn{2}{|c|}{ Total /season (mm) } & 762.1 & 567.1 & 525.0 & 990.5 \\
\hline
\end{tabular}

\section{Sesame Yield Function:}

Sesame seeds and oil yields response to water has been studied after harvesting. The yield response to water showed quadratic function for both seeds and oil as:

$$
Y=a+b X+c X^{2}
$$

Where:

Y (yield (kg/fed.)

$X$ total irrigation water $\left(\mathrm{m}^{3} / \mathrm{fed}\right.$.)

a, b, c regression coefficients 
Yield functions of seeds and oil for different irrigation system and coefficients of the regression analyses are presented in Table (11). The yield function and water use efficiency of seeds and oil for the best treatment (sub surface drip) presented in Fig.(11) and (12) respectively. Table (11): Regression coefficients of yield functions of seeds and oil for the irrigation systems

\begin{tabular}{|l|c|c|c|c|c|c|c|c|}
\hline \multirow{2}{*}{ System } & \multicolumn{2}{|c|}{$\mathrm{a}$} & \multicolumn{2}{c|}{$\mathrm{b}$} & \multicolumn{2}{c|}{$\mathrm{c}$} & \multicolumn{2}{c|}{$\mathrm{R}^{2}$} \\
\cline { 2 - 10 } & \multicolumn{1}{|c|}{ Seeds } & \multicolumn{1}{c|}{ oil } & Seeds & oil & \multicolumn{1}{c|}{ Seeds } & oil & Seeds & oil \\
\hline Drip surface & -3776.7 & -2345.8 & 3.19 & 1.935 & $-5.7 \mathrm{E}-4$ & $-3.53 \mathrm{E}-4$ & 0.96 & 0.95 \\
\hline Drip subsurface & -4032.2 & -2218.2 & 3.615 & 1.948 & $-6.9 \mathrm{E}-4$ & $-3.75 \mathrm{E}-4$ & 0.97 & 0.96 \\
\hline Sprinkler & -480.2 & -529.6 & 0.547 & 0.389 & $-6.82 \mathrm{E}-5$ & $-4.74 \mathrm{E}-5$ & 0.88 & 0.94 \\
\hline
\end{tabular}

To get the maximum yield of seeds or oil, the first derivative of the water yield function is set equal to zero and solving for $\mathrm{X}$, then applying the $\mathrm{X}$ value in the original yield function results in maximum yield. The same was done to get the maximum oil yield. The expected maximum yield of seeds and oil under the irrigation systems presented in Table (12). It is obvious that the subsurface drip irrigation system produce highest seeds and oils and has the least water use.

Table(12): Expected maximum yield of seeds and oil

\begin{tabular}{|l|c|c|c|}
\hline \multicolumn{1}{|c|}{ System } & $\begin{array}{c}\text { water } \\
\mathrm{m}^{3} / \mathrm{fed} .\end{array}$ & $\begin{array}{c}\text { Maximum seeds } \\
\text { yield }(\mathrm{kg} / \mathrm{fed} .)\end{array}$ & $\begin{array}{c}\text { Maximum oil } \\
\text { yield }(\mathrm{kg} / \mathrm{fed} .)\end{array}$ \\
\hline Drip surface & 2798.2 & 686.5 & 304.8 \\
\hline Drip subsurface & 2619.6 & 702.6 & 311.4 \\
\hline Sprinkler & 4010.3 & 616.7 & 268.1 \\
\hline
\end{tabular}

\section{Water Use Efficiency (WUE) of Sesame Seeds and Oil:}

The results of WUE of seeds $\left(\mathrm{WUE}_{\mathrm{s}}\right)$ and oil $\left(\mathrm{WUE}_{\mathrm{o}}\right)$ are presented in Table (13). The sub surface drip $\mathrm{WUE}_{\mathrm{s}}$ and $\mathrm{WUE}_{\mathrm{o}}$ are plotted against the irrigation water as given in Fig. (11) and Fig. (12) respectively. In the graph it was seen that WUE have the same trend as the yield function.

Effect of irrigation system and irrigation regime on yield and plant growth parameters:

The statistical analyses in Table (13), showed significant difference in irrigation water used by the irrigation systems, insignificant difference in 
oil yield by the irrigation systems, insignificant difference in seeds yield between surface and subsurface irrigation systems. The irrigation regime caused significant difference in yield of seeds and oil, and on their WUE. The data of sesame growth parameters are presented in Table (14). Results indicated that insignificant influence of the irrigation systems on the biological yield, plant height, weight of dry seeds/plant and oil content $\%$. The only exception was found in No. of cap./plant, where a significant difference found between the sprinkler irrigation system and the drip system, meanwhile no difference found in No. of capsules. The effect of irrigation regime was significant on all growth parameter.

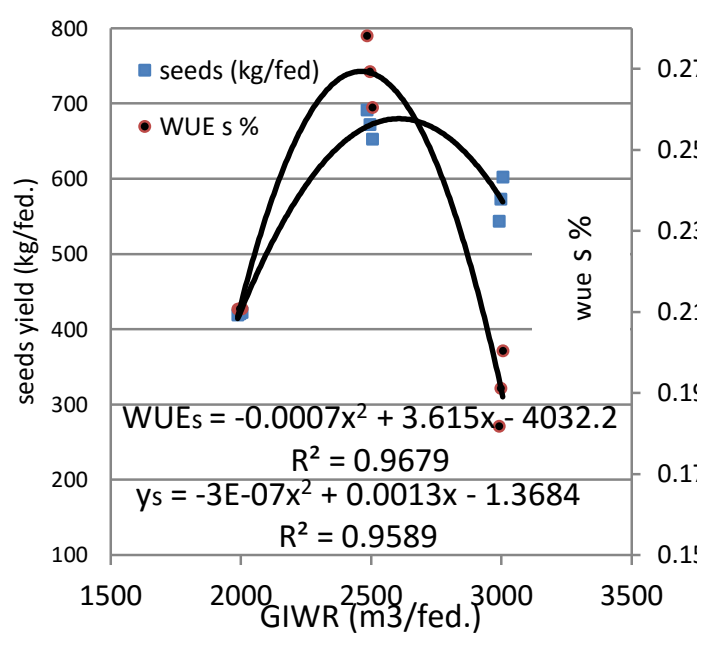

Fig. (11): yield function and water use efficiency of Sesame seeds (Subsurface drip)

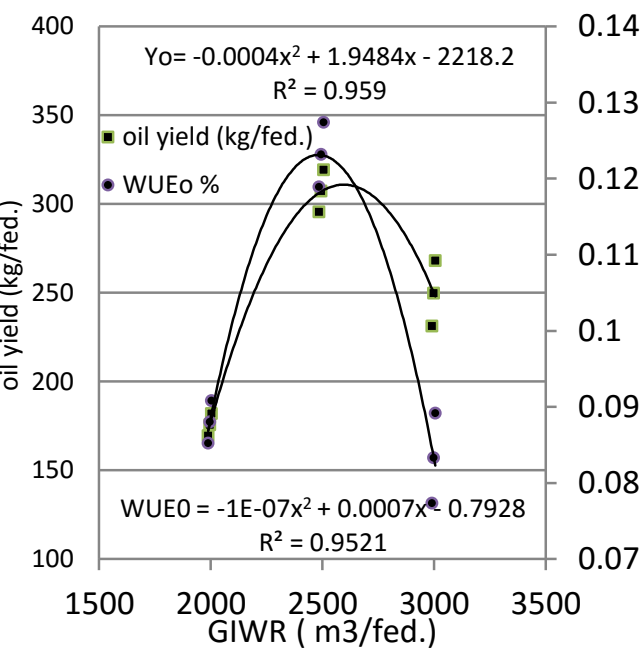

Fig. ( 12 ): yield function and water use efficiency of Sesame oil (sub surface drip)

\section{Relationship Between Biological Yield and the Growth Parameters:}

Results indicated high linear relationship between the biological yield and most of other yield parameters as shown in Fig. (13) and Fig. (14). The correlations between the biological yield and seeds yield, oil yield and plant height are 0.98, 0.93 and 0.92 respectively. The same trend was noticed between the biological yield and No. of capsules/plant, weight of dry seeds/plant and weight of 1000 seeds. The correlations were 0.84 , 0.97 and 0.8 respectively. 


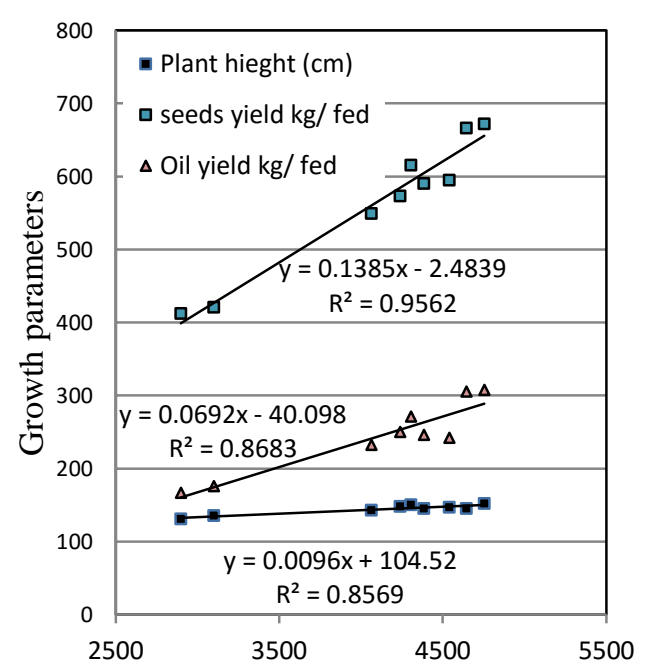

Biological yield kg/fed

Fig (13): Biological yield versus plant height, seeds yield and oil yield

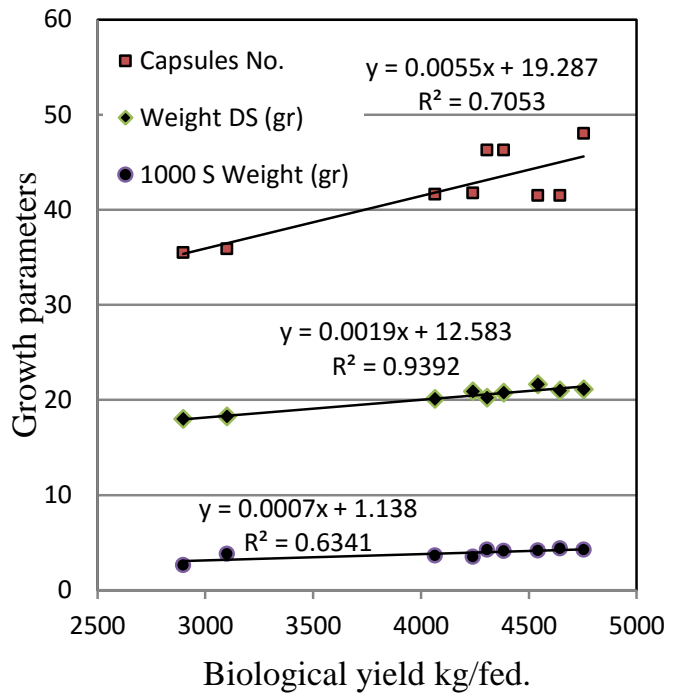

Fig (14): Biological yield versus No. of cap., weight of DS and 1000 seeds/plant

Table. (13): Effect of irrigation system and irrigation regime on Sesame production.

\begin{tabular}{|c|c|c|c|c|c|c|}
\hline \multirow{2}{*}{ 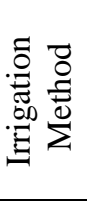 } & \multirow{2}{*}{ 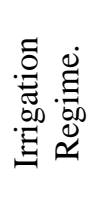 } & \multirow{2}{*}{ 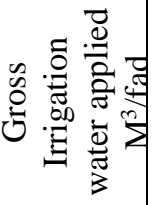 } & \multirow{2}{*}{ 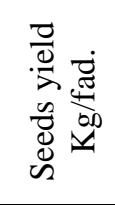 } & \multirow{2}{*}{ 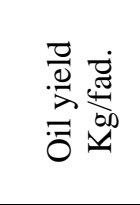 } & \multicolumn{2}{|c|}{$\begin{array}{l}\text { Water productivity } \\
\left(\mathrm{kg} / \mathrm{m}^{3} \text { water }\right)\end{array}$} \\
\hline & & & & & Seeds & Oil \\
\hline $\mathrm{I}_{1}$ & & $2641 \mathrm{a}$ & $557 \mathrm{~b}$ & $237.9 \mathrm{a}$ & $0.2116 \mathrm{~b}$ & $0.0902 \mathrm{~b}$ \\
\hline $\mathrm{I}_{2}$ & & $2496 \mathrm{~b}$ & $555 \mathrm{~b}$ & $244.3 \mathrm{a}$ & $0.2273 \mathrm{a}$ & $0.0982 \mathrm{a}$ \\
\hline $\mathrm{I}_{3}$ & & $4193 \mathrm{c}$ & 585 a & $249.8 \mathrm{a}$ & $0.1434 \mathrm{c}$ & $0.0612 \mathrm{c}$ \\
\hline \multicolumn{2}{|c|}{ LSD.05 $_{.05}$} & 69.0 & 11.8 & 15.04 & 0.007 & 0.004 \\
\hline & $\mathrm{D}$ & $2512 \mathrm{c}$ & $474 \mathrm{c}$ & $196.0 \mathrm{c}$ & $0.1929 \mathrm{~b}$ & $0.0796 \mathrm{~b}$ \\
\hline & $\mathrm{N}$ & $3099 \mathrm{~b}$ & $651 \mathrm{a}$ & $244.6 \mathrm{a}$ & $0.2231 \mathrm{a}$ & $0.1013 \mathrm{a}$ \\
\hline & $\mathrm{E}$ & $3720 \mathrm{a}$ & $572 \mathrm{~b}$ & $241.0 \mathrm{~b}$ & $0.1629 \mathrm{c}$ & $0.0687 \mathrm{~b}$ \\
\hline \multicolumn{2}{|c|}{ LSD.05 $_{.05}$} & 31.0 & 21.8 & 24.91 & 0.0097 & 0.0158 \\
\hline & $\mathrm{D}$ & 2112.5 & 411.9 & 166.6 & 0.1951 & 0.0789 \\
\hline \multirow[t]{3}{*}{$\mathrm{I}_{1}$} & $\mathrm{~N}$ & 2641.0 & 666.3 & 305.3 & 0.2522 & 0.1155 \\
\hline & $E$ & 3169.5 & 594.4 & 242.1 & 0.1875 & 0.0764 \\
\hline & $\mathrm{D}$ & 1996.0 & 420.6 & 175.7 & 0.2107 & 0.0880 \\
\hline \multirow[t]{3}{*}{$\mathrm{I}_{2}$} & $\mathrm{~N}$ & 2495.0 & 671.9 & 307.4 & 0.2693 & 0.1232 \\
\hline & $E$ & 2998.5 & 573.1 & 249.8 & 0.1911 & 0.0833 \\
\hline & D & 3428.0 & 589.9 & 246.2 & 0.1723 & 0.0719 \\
\hline \multirow[t]{2}{*}{$\mathrm{I} 3$} & $\mathrm{~N}$ & 4159.5 & 615.0 & 271.2 & 0.1479 & 0.0652 \\
\hline & $\mathrm{E}$ & 4992.5 & 548.8 & 232.0 & 0.1100 & 0.0465 \\
\hline \multicolumn{2}{|c|}{$\mathrm{SD}_{05}$} & $* * *$ & $* *$ & $* *$ & $* * *$ & $* * *$ \\
\hline
\end{tabular}


Table. (14): Effect of irrigation methods and irrigation regime on Sesame yield components.

\begin{tabular}{|c|c|c|c|c|c|c|}
\hline $\begin{array}{l}\text { Irrigation } \\
\text { Method }\end{array}$ & $\begin{array}{l}\text { Irrigation } \\
\text { Regime }\end{array}$ & $\begin{array}{c}\text { Biological } \\
\text { Yield } \\
\mathrm{kg} / \mathrm{fad}\end{array}$ & $\begin{array}{l}\text { Plant } \\
\text { height } \\
(\mathrm{cm})\end{array}$ & $\begin{array}{c}\text { No. of } \\
\text { Capsule/ } \\
\text { plant }\end{array}$ & $\begin{array}{l}\text { Weight dry seed } \\
\text { / plant (gm) }\end{array}$ & Oil\% \\
\hline $\mathrm{I}_{1}$ & & $4026.7 \mathrm{a}$ & $140.75 \mathrm{a}$ & $39.5 \mathrm{~b}$ & $20.21 \mathrm{a}$ & $42.33 \mathrm{a}$ \\
\hline $\mathrm{I}_{2}$ & & $4031.6 \mathrm{a}$ & $145.08 \mathrm{a}$ & $42.9 \mathrm{~b}$ & $20.08 \mathrm{a}$ & $43.75 \mathrm{a}$ \\
\hline $\mathrm{I}_{3}$ & & $4251.3 \mathrm{a}$ & $145.79 \mathrm{a}$ & $44.7 \mathrm{a}$ & $20.38 \mathrm{a}$ & $42.79 \mathrm{a}$ \\
\hline \multicolumn{2}{|c|}{ LSD $_{.05}$} & 256.86 & 5.24 & 1.82 & 0.77 & 1.95 \\
\hline & $\mathrm{D}$ & $3460.0 \mathrm{c}$ & $136.96 \mathrm{c}$ & $39.21 \mathrm{c}$ & $19.00 \mathrm{~b}$ & $41.29 c$ \\
\hline & $\mathrm{N}$ & $4567.8 \mathrm{a}$ & $148.91 \mathrm{a}$ & $45.27 \mathrm{a}$ & $20.74 \mathrm{a}$ & $45.33 \mathrm{a}$ \\
\hline & $E$ & $4281.7 \mathrm{~b}$ & $145.75 \mathrm{~b}$ & $41.63 \mathrm{~b}$ & $20.88 \mathrm{a}$ & $42.25 \mathrm{~b}$ \\
\hline \multicolumn{2}{|c|}{$\mathrm{LSD}_{.05}$} & 169.9 & 2.31 & 0.714 & 0.99 & 0.94 \\
\hline \multirow[t]{3}{*}{$\underline{I}_{1}$} & $\mathrm{D}$ & 2898.0 & 130.6 & 35.50 & 18.00 & 40.38 \\
\hline & $\mathrm{N}$ & 4644.1 & 145.0 & 41.50 & 21.00 & 45.88 \\
\hline & $\mathrm{E}$ & 4540.8 & 146.6 & 41.50 & 21.63 & 40.75 \\
\hline \multirow[t]{3}{*}{$\mathrm{I}_{2}$} & $\mathrm{D}$ & 3100.8 & 135.4 & 35.88 & 18.25 & 41.75 \\
\hline & $\mathrm{N}$ & 4753.3 & 151.9 & 48.00 & 21.13 & 46.00 \\
\hline & $\mathrm{E}$ & 4239.5 & 148.0 & 41.75 & 20.88 & 43.50 \\
\hline \multirow[t]{3}{*}{$\mathrm{I}_{3}$} & $\mathrm{D}$ & 4383.8 & 144.9 & 46.25 & 20.75 & 41.75 \\
\hline & $\mathrm{N}$ & 4305.9 & 149.9 & 46.25 & 20.25 & 44.13 \\
\hline & $\mathrm{E}$ & 4064.1 & 142.6 & 41.63 & 20.13 & 42.50 \\
\hline \multicolumn{2}{|c|}{ LSD. } & $* *$ & $* *$ & $* *$ & $* *$ & $* *$ \\
\hline
\end{tabular}

Mean values having the same letter(s) are not significantly different based on LSD $_{0.05} \mathrm{n}$ s: not significant. Surface drip irrigation $\left(\mathbf{I}_{1}\right)$., Subsurface drip irrigation $\left(I_{2}\right)$ and Sprinkler irrigation $\left(I_{3}\right)$. Deficit irrigation $(D=80 \%$ of ETc $)$, Normal irrigation ( $N=100 \%$ of ETc $)$ and Excessive irrigation $(E=120 \%)$

\section{CONCLUSION}

From the obtained results it could be concluded that:

- FAO method for adjusting the crop coefficient is highly accurate. This was confirmed by comparing the actual crop coefficient of sesame that resulted from measuring the water consumptive use by the adjusted crop coefficient under drip surface, drip subsurface and sprinkler irrigation systems that operated at semi-arid conditions and sandy soil. The correlation coefficient between the adjusted sesame crop coefficient and the actual crop coefficient were $0.89,0.87$ and 0.9 respectively.

- The gross irrigation water requirements for sesame crop cultivated in sandy soil by drip surface, drip sub surface and sprinkler irrigation systems were $628 . \mathrm{mm} / \mathrm{season}\left(2641 \mathrm{~m}^{3} / \mathrm{fed}\right.$.) , $596.3 \mathrm{~mm} / \mathrm{season}(2496$ $\mathrm{m}^{3} /$ fed.) and $990 \mathrm{~mm} / \mathrm{season}\left(4193 \mathrm{~m}^{3} /\right.$ fed.), respectively. 
- The relationship between the sesame water consumptive use and evapotranspiration indicated that the consumptive use in all cases is less than the evapotranspiration due to the water stored in plant tissue. The correlation coefficient between the consumptive use and the evapotranspiration under drip surface, drip subsurface and sprinkler irrigation systems were, $0.93,0.94$, and 0.92 respectively.

- The irrigation system indicated significant effect on gross irrigation water used and water use efficiency of both seeds and oil. Insignificant effect was found on oil yield, biological yield and plant height. The irrigation regimes indicated significant effect on gross irrigation water used and on all other yield parameters and components.

- Among all the study treatments, the application of subsurface drip irrigation system at $100 \%$ of ETc indicated the best results related to the yield of seeds and oil and the other yield components, although, there is no significant difference between the irrigation water used between the subsurface drip and surface drip irrigation

- The same conclusion was remarked from yield function when applying maximum irrigation water for the irrigation systems. The subsurface drip irrigation system produced $702.6 \mathrm{~kg}$ seeds/fed. and $311.4 \mathrm{~kg}$ oil/fed. when $2619.6 \mathrm{~m}^{3}$ water was added per fed., meanwhile the surface drip irrigation system produced $686.5 \mathrm{~kg}$ seeds/fed. and $304.8 \mathrm{~kg}$ oil/fed. when $2798.2 \mathrm{~m}^{3}$ water was added per fed. The sprinkle irrigation system produced $616.7 \mathrm{~kg}$ seeds/fed. and $268.1 \mathrm{~kg}$ oil $/$ fed. when $4010.3 \mathrm{~m}^{3}$ water was added per fed..

\section{REFERENCES}

ASAE Standers 2001 : Standers, Engineering practices, data. No. 47143403. Amer. Soc. Agric. Eng., St. Joseph, MI. pp 1027

ASCE, Describing Irrigation Efficiency and Uniformity. J. Irrig. Drain. Div., ASCE 1978, 104 (IRI), 35-41.

Allen, R. G., L. S. Pereira; D. Raes and Smith. 1998. Crop evapotranspiration. FAO Irrigation and Drainage Paper No. 56, Rome, Italy. 297 pp. 
Benami, I. and A. Ofen 1984. Irrigation Engineering. Irrigation Engineering Publications (IESP), Haifa, Israel. 257 pp.

Black, C. A., D. D. Evans, L.E.Ensminger, J. L. White, F. E. Clark and R. C. Dinauer. 1985. Methods of soil analyses. Seven Printing. Amer. Soc. of Agro. Madison, Wisconsin USA.

Christiansen J.E. (1942): Irrigation by Sprinkling. California Agriculture Experiment Station Bulletin, No. 670

CoHort Software (2005). Costat Statistical package (version 6.311), P.O.Box 1149, Berkeley, CA, 94701, USA.

Doorenbos, J. and W. O. Pruit (1977). Guideline for predicting crop water requirments. FAO, Irrig. and Drain. Paper No. 24 pp: 122- 132

El-Wakil, A.M. and S.A. Gaafar, (1988). Effect of water stress on sesame. Assiut J. Agric. Sci., 9: 363-374.

Erkan. B., D., Mehmet, M. Simsekd and S Gereck. (2007). Effect of irrigation methods and irrigation intervalsspacing on yield and yield components of sesame growing in arid area. J. of Agronomy 6 (3): 439-443.

Kassab O.M., A.A. El-Noemani and H.A. El-Zeiny , (2005). Influence of Some Irrigation Systems and Water Regimes on Growth and Yield of Sesame Plants. J. of Agronomy, 4: 220-224.

Li J and Rao M., 2004. Crop yield as affected by uniformity of sprinkler irrigation system. Agricultural Eng. Int: the CIGR J. Sci. Res. Dev. Manuscript LW01 004, 111.

Manal M. T., S. A. Ouda and F. A. Khalil. (2007). Irrigation Optimization for Different Sesame Varieties Grown under Water Stress Conditions. J of Applied Sciences Research, 3(1): 7-12.

Merriam J.L., Keller J. (1978): Farm Irrigation System Evaluation: A Guide for Management. Department of Agricultural and Irrigation Engineering, Utah State University, Logan.271 pp.

Molden D. 2003. A water-productivity framework for understanding and action in: Kijne, J.W., Barker, R Molden, D. (Eds.), Water Productivity in Agriculture: Limits and Opportunities for 
Improvement .International Water Management Institute, Colombo, Sri Lanka, pp. 1-18.

Simonne, E. H. and M. D. Dukes, 2010. Principles and practices of irrigation management for vegetables. University of Florida, Hort. Sci. Extension. pp 17-23.

Solomon, K. (1977). Evaluation criteria for trickle irrigation emission devices. Proc. 4th Annu. Int. Drip Irrig. Assoc. Meet. pp. 65-76.

Vermeieren, I. and Gobling G. A., 1980. Localized irrigation. Design, installation, operation, evaluation. FAO paper No. 36.

Walker, W.R. 1980. Sprinkler and Trickle Irrigation. Colorado Sate University, Fort Collins, Colorado 80523. 10 Chapters.

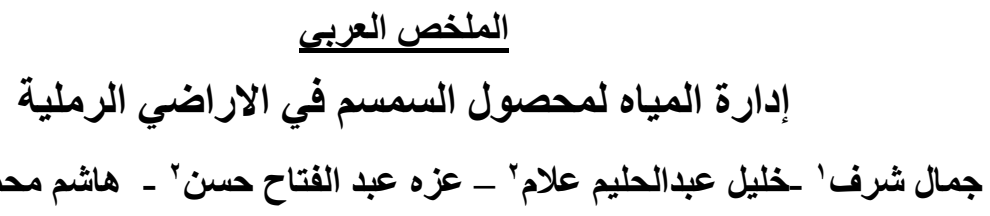

تم اجراء تجربة حقلية بمنطقة البستان لدراسة ادارة المياه لمحصول السمسم لموسمين زراعيين

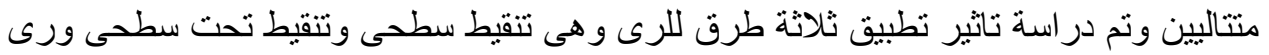

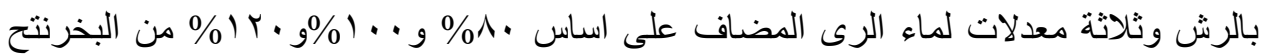

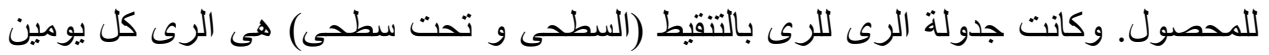

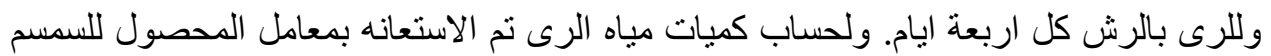

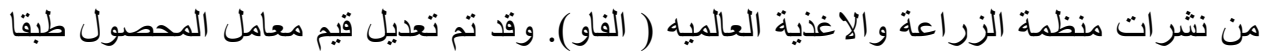

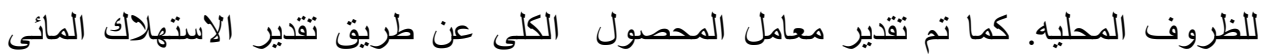

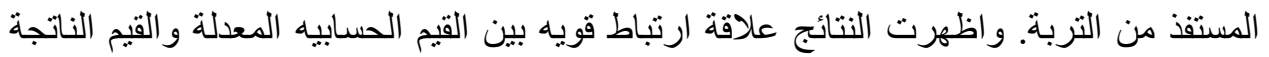

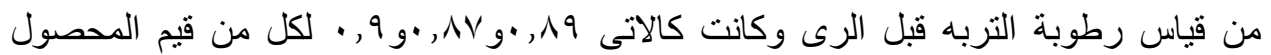

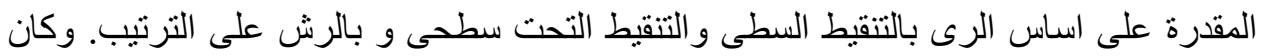

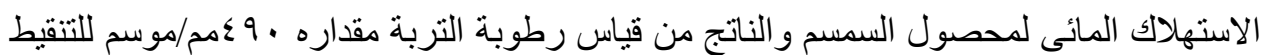

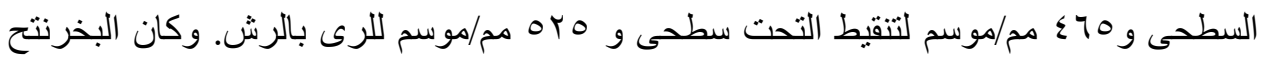

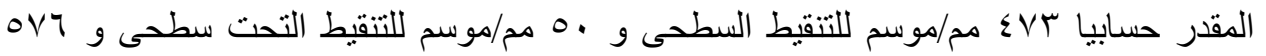

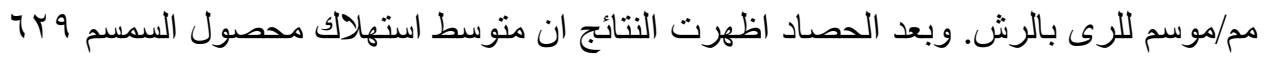

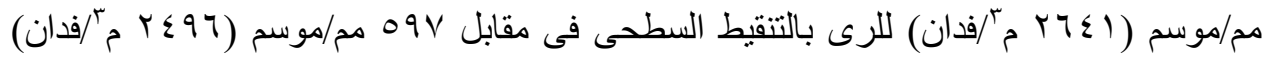

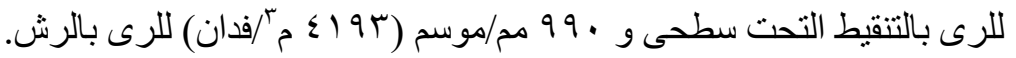


نتج عن هذه الكمات من مياه الرى محصول كامل بمقدار rV . • كج/فدان و rr • ك كج/فدان و 10 النتائج احصائيا (فيما يخص نظم الرى أو المعاملات الرئيسية) ظهور فروق معنويه فى كميات

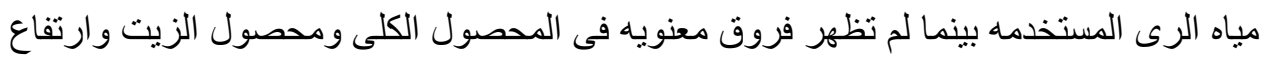

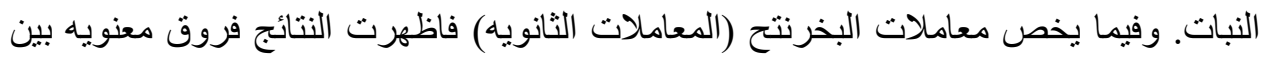

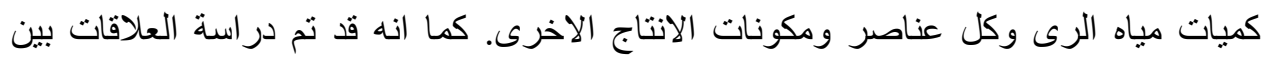

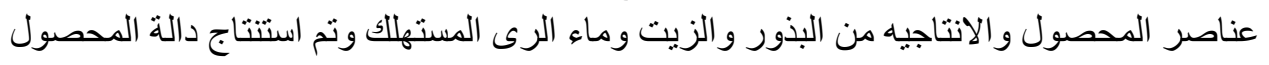

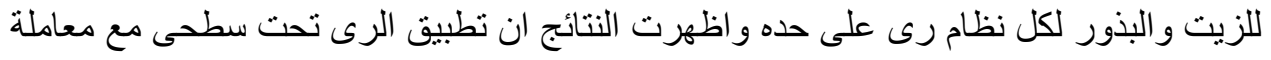

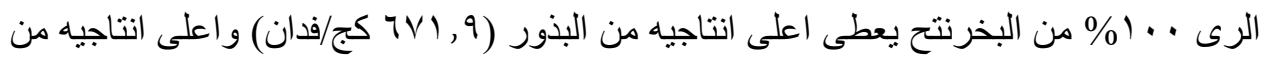

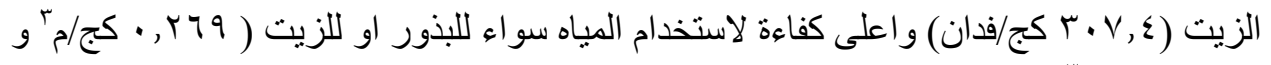

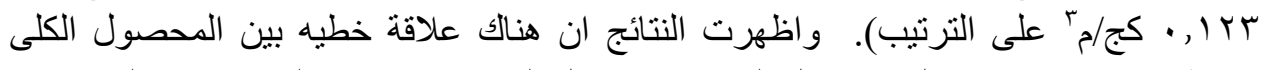

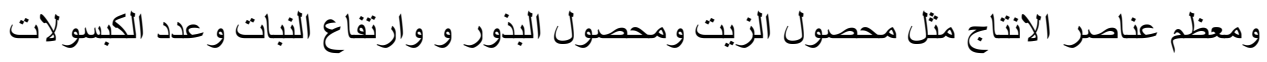

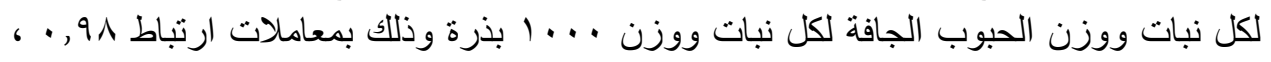

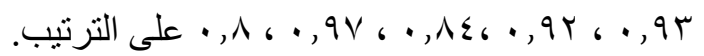

